\title{
Experimental Investigation of Cigarette Butts as a Trigger on Smoldering Combustion Propagation of Peat: Case Study on Pelelawan Peat
}

\author{
Awaludin Martin ${ }^{\text {a }}$, Yogi Wibowo Agusta ${ }^{\text {a }}$, Pither Palamba ${ }^{\text {a }}$ \\ a) Department of Mechanical Engineering, Faculty of Engineering, Riau University, Pecuniary, Indonesia \\ b) Department of Mechanical Engineering, Faculty of Engineering, Cenderawasih University, Jayapura, Indonesia \\ *Corresponding author: awaludinmartin01@gmail.com
}

\section{Paper History}

Received: 30-August-2020

Received in revised form: 15 -October-2020

Accepted: 30-November-2020

\begin{abstract}
Peatland fires are a problem every year in Indonesia especially in Sumatera Island. In Riau during the dry season, there will be peatland fires that are difficult to extinguish. There are several reasons for peatland fires and this study will analyze whether cigarette butts can cause peat fires or not. In this research peat sample was dried at $35-45^{\circ} \mathrm{C}$ and at temperature at $115^{\circ} \mathrm{C}$ to reduce water content in peat samples. Cigarette butts as a trigger were prepared with a length of $30 \mathrm{~mm}$ and tested on a bomb calorimeter to determine their calorific values. The cigarette butts with the highest HHV (High Heating Value) were used and burned on the surface of the peat sample by adding airflow to the sample with varying flow rates. The fastest of smoldering combustion propagation velocity was obtained $785 \mathrm{~mm} /$ hour for vertical direction and $1336 \mathrm{~mm} /$ hour for horizontal direction with speed of airflow of $5 \mathrm{~m} / \mathrm{s}$. The highest temperature was obtained in the experiment of $902^{\circ} \mathrm{C}$ with the speed of airflow of $5 \mathrm{~m} / \mathrm{s}$.
\end{abstract}

KEY WORDS: Peat, Smoldering, Propagation.

\section{NOMENCLATURE}

$T \quad$ Temperature

$V \quad$ Airflow Velocity

$A$ average Average airflow velocity

HHV High Heating Value

\subsection{INTRODUCTION}

The peatlands are a land of ecosystems, which play a major role in maintaining carbon, water and climate balance [1]. Tropical countries, including Indonesia have the largest area of peatlands, around 20.6 million ha, which are mostly spread over the three major islands of Kalimantan (32\%), Sumatra (35\%), and Papua (30\%) [2]. Riau Province holds peatland about $19.5 \%$ areas in Indonesia and second ranks as the largest peatland area among other peat regions in the country [3].

Fire is a possible cause of peatland degradation causing rapid depletion of peat function [4]. Fires on peatlands not only burn vegetation and peat layers, but also disturb the ecosystem as a whole [5]. Every year the problem of peatland fires was a very dangerous phenomenon with high emission and smoldering combustion. Peatland fires burned soil in very large-scale, which can damage physical and chemical parts of the peats [6]. Peatland fires have a smoldering combustion, which burning soil in low speed and low temperature at dry season [7].

Land fires that occur in Indonesia are caused by three main factors namely the state of the fuel, weather, and intentional [8]. The condition of a fuel that is prone to danger, climatic factors such as temperature, humidity, wind and rainfall also determine the level of fire hazard, intentional factors have the largest share of the existence of land in Indonesia. There are several allegations of burning of peatlands, one of Intentional burning is to get a grazing field or new field for another business by throwing cigarette butt that is still burning in peatland can cause a fire without the cost of opening new fields [9].

The aim of this research is to prove whether peatland fires are caused by cigarette butts or not and if smoldering combustion propagation occurred, how fast velocity caused by cigarette butts with airflow effect which used average wind of Riau Province, Indonesia. 


\subsection{METHODOLOGY}

The sample of peat in this research was collected from the Pelelawan area in Riau Province, Indonesia.

\subsection{Materials}

\section{Samples Preparation}

Electric oven type Squaroid Duo-Vac Oven Lab Line, with specifications of 230/240 Volts, 1400W, 5.8 A and dimensions of $400 \times 400 \times 330 \mathrm{~mm}$ were used to dry samples with temperature at $35-45^{\circ} \mathrm{C}$ (this temperature is assumed similar with environment condition) and $115^{\circ} \mathrm{C}$ with a drying time in 8 hours. Mass of the sample was measured before drying and after drying. The purpose of drying samples is to make easier or speed up the process of samples burning [10]. After peat samples are dried, mass loss can be show in Table 1 .

Table 1: Drying Peat Samples

\begin{tabular}{ccc}
\hline Mass (gram) & Temperature $\left({ }^{\circ} \mathrm{C}\right)$ & Mass Loss $(\%)$ \\
\hline \multirow{3}{*}{1000} & 35 & 16 \\
\cline { 2 - 3 } & 40 & 24 \\
\cline { 2 - 3 } & 45 & 26 \\
\cline { 2 - 3 } & 115 & 80 \\
\hline
\end{tabular}

Cigarettes Butts Preparation

High Heating Value (HHV) of cigarette butts were measure by calorimeter bomb tool type C-200 which used three different cigarettes, it has needed to know the quality of burning peat samples. The cigarettes that used for this research is $30 \mathrm{~mm}$ as cigarette butts. The HHV of cigarettes can be show in Table 2.

Table 2: The HHV of Cigarettes

\begin{tabular}{cccc}
\hline Cigarette Types & $\begin{array}{c}\text { Length } \\
(\mathrm{mm})\end{array}$ & Mass (gram) & HHV (J/gram) \\
\hline A & \multirow{2}{*}{30} & 0,625 & 9471,49 \\
\cline { 3 - 4 } & & 0,715 & 10991,89 \\
\cline { 3 - 4 } $\mathrm{B}$ & & 0,512 & 7722,63 \\
\hline $\mathrm{C}$ & & &
\end{tabular}

\subsection{Experimental Setup}

The experimental settings will be run on the Wind Tunnel Subsonic Type with the maximum speed around of $5 \mathrm{~m} / \mathrm{s}$. The Specification of Wind Tunnel dimension are Settling Chambers length is $530 \mathrm{~mm}$, Contractions length is $472.5 \mathrm{~mm}$, Test Chamber length and Hydraulic Diameter are $396 \mathrm{~mm}$ and 198 $\mathrm{mm}$, and the Diffuser length is $588 \mathrm{~mm}$ as shown in Figure 1.

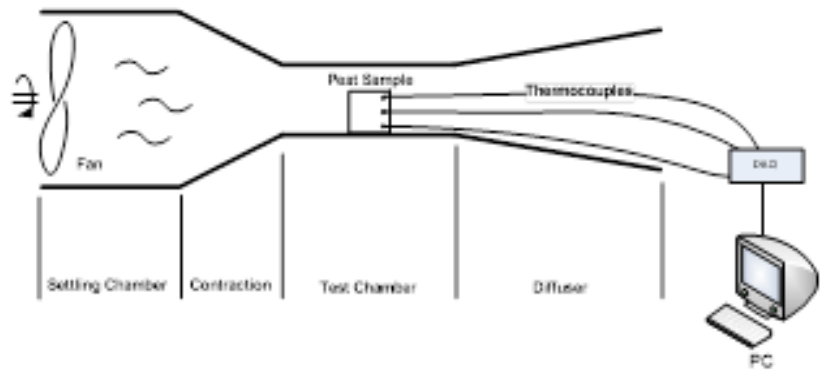

Figure 1: Schematic Experimental Setup

\subsection{Experimental Preparation}

Peat samples was burned in the Reactor Box with size 100x100x100 mm and this box is made by Iron Cast material and Plywood case to reduce the heat loss. The reactor box has 8 holes were perforated for laying thermocouples that arranged symmetrically with a distance of $25 \mathrm{~mm}$ between other thermocouples. Thermocouples were used type $\mathrm{K}$ with maximum temperature $1200^{\circ} \mathrm{C}$ and recorded by using Data Acquisition System type Advantech USB-4718 that connected to Desktop Computer. The experiment equipment or box of peat sample can be shown in Figure 2.

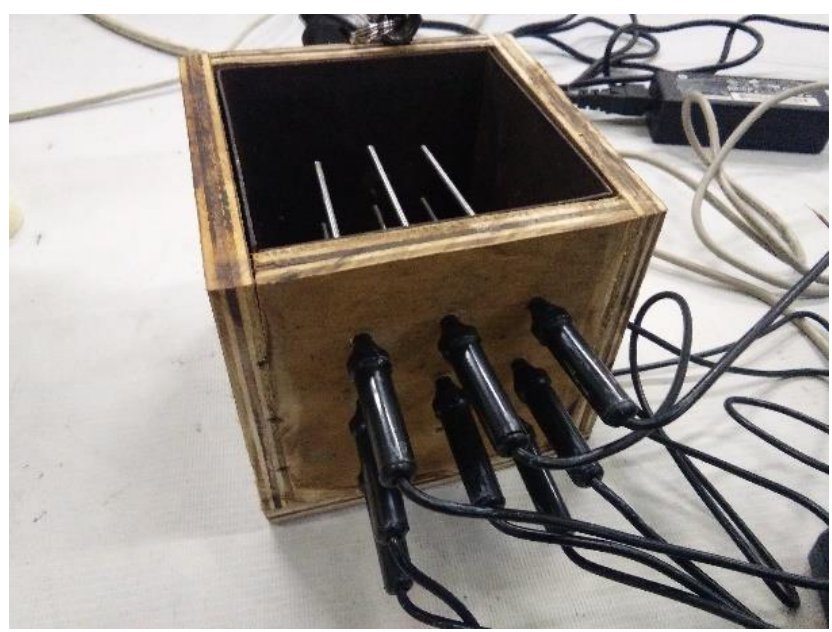

Figure 2: Experimental Equipment and Thermocouple Position

\subsection{Experimental Procedure}

Smoldering combustion propagation experiment procedures are follows:

1. The different peat sample was put into reactor box.

2. Thermocouples were connected to DAQ System.

3. Equipment and peat samples were place into Wind Tunnel

4. The anemometer used to measure the velocity of airflow.

5. Collected data was begin when the reactor box is fill with peat samples and cigarette butt with highest HHV was use and burned on the surface of peat sample.

6. Collecting data is stop after all the samples have burned and all thermocouple temperatures are below 50 degrees Celsius.

\subsection{RESULT AND DISCUSSION}

In this study, the peat samples were dried in two parts of the activity. First, the peat sample was dried under natural weather conditions, namely at a temperature of $35 \mathrm{C}$ to a maximum of 45C. Secondly, peat sample was dried at temperatures up to $115^{\circ} \mathrm{C}$ to reduce all of water content in the peat sample.

\subsection{Peat Dried at Temperature $35-45^{\circ} \mathrm{C}$}

Peat drying samples of $35-45^{\circ} \mathrm{C}$ was unburned although with airflow speed at 3-5 m/s. It can be shown in Table 3, there are not significant difference of temperature at any point of thermocouple, it mean the peat sample is unburned. 
Table 3: Temperature of Thermocouples at Each Point

\begin{tabular}{cccc}
\hline \multirow{2}{*}{ Thermocouple } & \multicolumn{3}{c}{ Dried Temperature of Samples $\left({ }^{\circ} \mathrm{C}\right)$} \\
\cline { 2 - 4 } & $35^{\circ} \mathrm{C}$ & $40^{\circ} \mathrm{C}$ & $45^{\circ} \mathrm{C}$ \\
\hline $\mathrm{T} 1$ & 28 & 31 & 31 \\
\hline $\mathrm{T} 2$ & 27 & 29 & 30 \\
\hline $\mathrm{T} 3$ & 27 & 30 & 30 \\
\hline $\mathrm{T} 4$ & 30 & 28 & 28 \\
\hline $\mathrm{T} 5$ & 30 & 29 & 28 \\
\hline $\mathrm{T} 6$ & 29 & 28 & 27 \\
\hline $\mathrm{T} 7$ & 30 & 30 & 29 \\
\hline $\mathrm{T} 8$ & 31 & 30 & 29 \\
\hline
\end{tabular}

\subsection{Peat Dried at Temperature $115^{\circ} \mathrm{C}$}

There was combustion in the peat sample, which was dried at temperature of $115^{\circ} \mathrm{C}$ by adding airflow to the sample with an airflow rate of air of $3 \mathrm{~m} / \mathrm{s}, 4 \mathrm{~m} / \mathrm{s}$ and $5 \mathrm{~m} / \mathrm{s}$.

\subsection{Discussion}

In this experiment, combustion was performed with cigarette butts as a trigger and it was conducted with several variant of airflow speed, namely $3 \mathrm{~m} / \mathrm{s}, 4 \mathrm{~m} / \mathrm{s}$ and $5 \mathrm{~m} / \mathrm{s}$. Experiments were conducted to determine the speed of combustion propagation in both the vertical and horizontal directions.

\section{Propagation on Vertical Direction}

Smoldering combustion propagation on vertical direction can be monitor from all thermocouples data. After all of data from thermocouples gathered by time, the data will calculated by determining the temperature reference point to equalize the temperature of each thermocouple in order to obtain the difference in time of reaching the temperature.

The temperature reference is $300^{\circ} \mathrm{C}$, which is calculated by the distance each thermocouples and divided by the time difference between the thermocouple below to determine the vertical propagations speed [7]. Thermocouples related with other thermocouples for the time difference in reaching is thermocouple $1(\mathrm{THz})$ to thermocouple $4(\mathrm{THz})$ to get $\mathrm{v} 1$, thermocouple 2 (THz) to thermocouple $5(\mathrm{THz})$ to get $\mathrm{v} 2$, and so on. The scheme of point of temperature can be shown in Figure 3.

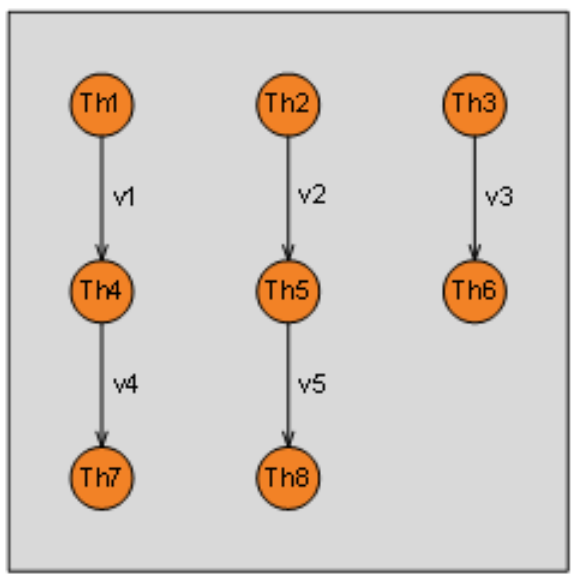

Figure 3: Vertical Smoldering Combustion Propagation
From the difference time obtained between the thermocouples when the combustion temperature reaches $300^{\circ} \mathrm{C}$, smoldering combustion propagation on the vertical direction in each velocity by adding airflow rate of $5 \mathrm{~m} / \mathrm{s}$ on peat sample can be seen in Table 4.

Table 4: Propagation Speed in Vertical Direction

\begin{tabular}{ccccc}
\hline $\mathrm{v} 1(\mathrm{~mm} / \mathrm{hr})$ & $\begin{array}{c}\mathrm{v} 2 \\
(\mathrm{~mm} / \mathrm{hr})\end{array}$ & $\begin{array}{c}\mathrm{v} 3 \\
(\mathrm{~mm} / \mathrm{hr})\end{array}$ & $\begin{array}{c}\mathrm{v} 4 \\
(\mathrm{~mm} / \mathrm{hr})\end{array}$ & $\begin{array}{c}\mathrm{v} 5 \\
(\mathrm{~mm} / \mathrm{hr})\end{array}$ \\
\hline 726 & 969 & 980 & 733 & 517 \\
\hline
\end{tabular}

The average of smoldering combustion propagation speed in vertical direction is as following:

$$
\begin{aligned}
\mathrm{v}_{\text {average }} & =\frac{\mathrm{v} 1+\mathrm{v} 2+\mathrm{v} 3+\mathrm{v} 4+\mathrm{v} 5}{5} \\
\mathrm{v}_{\text {average }} & =785 \mathrm{~mm} / \mathrm{hour}
\end{aligned}
$$

\section{Propagation on Horizontal Direction}

Same as vertical directions calculation, but thermocouples related with other thermocouples for the time difference in reaching of thermocouple 2 (Th2) to thermocouple 1 (Th1) to get v1, thermocouple 2 (Th2) to thermocouple 3 (Th3) to get v2, and so on. The scheme of point of temperature can be seen in Figure 4.

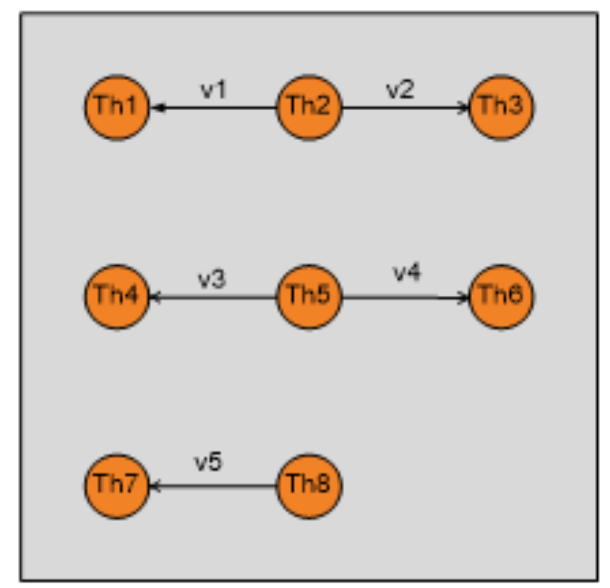

Figure 4: Horizontal Smoldering Combustion Propagation

From the time difference was obtained between the thermocouples when the combustion temperature reaches $300^{\circ} \mathrm{C}$, the smoldering combustion propagation on the horizontal direction in each velocity by adding airflow rate of $5 \mathrm{~m} / \mathrm{s}$ on peat sample can be show in Table 5 .

Table 5: Propagation Speed in Horizontal Direction

\begin{tabular}{ccccc}
\hline $\begin{array}{c}\mathrm{v} 1 \\
(\mathrm{~mm} / \mathrm{hr})\end{array}$ & $\mathrm{v} 2(\mathrm{~mm} / \mathrm{hr})$ & $\begin{array}{c}\mathrm{v} 3 \\
(\mathrm{~mm} / \mathrm{hr})\end{array}$ & $\begin{array}{c}\mathrm{v} 4 \\
(\mathrm{~mm} / \mathrm{hr})\end{array}$ & $\begin{array}{c}\mathrm{v} 5 \\
(\mathrm{~mm} / \mathrm{hr})\end{array}$ \\
\hline 960 & 1968 & 714 & 2000 & 1201 \\
\hline
\end{tabular}

The average of smoldering combustion propagation speed in horizontal direction is as following: 
ISOMAse

Intemational Society of Ocean, Mechanical and Aerospace soentits mos Evinoeen
Journal of Ocean, Mechanical and Aerospace

-Science and Engineering-

$3^{\text {th }}$ November 2020. Vol.64 No.3

(C) 2012 ISOMAse, All rights reserved

$$
\begin{aligned}
\mathrm{v}_{\text {average }} & =\frac{\mathrm{v} 1+\mathrm{v} 2+\mathrm{v} 3+\mathrm{v} 4+\mathrm{v} 5}{5} \\
\mathrm{v}_{\text {average }} & =1366 \mathrm{~mm} / \mathrm{hour}
\end{aligned}
$$

\section{Temperature Distribution at Variations in Airflow Rate}

The temperature distribution data was needed to determine the speed of smoldering combustion propagation on peat, so that by using this data, it can be anticipate against the spread of peat fires.

In this experiment was found the highest temperature on combustion of the sample reaches $902^{\circ} \mathrm{C}$ with an airflow velocity at $5 \mathrm{~m} / \mathrm{s}$. The longest combustion and propagation was occurred in samples with an airflow rate of $3 \mathrm{~m} / \mathrm{s}$ for more than 2 hours until all samples were burned. After all of data were collected and calculated the combustion velocity for each difference airflow velocity recapitulated and it can be seen in the Table 6 .

In Figure 5 shows the 3 groups of temperature data, firstly is the data group at the top of the sample (T1, T2 and T3), the secondly is the data group in the middle of the sample (T4, T5 and T6) and the third is the data group at the bottom of the sample (T7 and T8).

At the top of the sample, the peat was burn first and then it would spread to the middle, so that the sample in the middle would also burn and then would spread to the bottom. This was explained in Figure 5, where the temperature at points 1-3 has increased first than the others. In Figure 5, it is also shows the smoldering combustion propagation of peat is occurred.

\begin{tabular}{|c|c|c|c|}
\hline \multirow{2}{*}{$\begin{array}{c}\text { Drying } \\
\text { Temp. }\left({ }^{\circ} \mathrm{C}\right)\end{array}$} & \multirow{2}{*}{$\begin{array}{l}\text { Airflow rate } \\
(\mathrm{m} / \mathrm{s})\end{array}$} & \multicolumn{2}{|c|}{ Propagation Speeds $(\mathrm{mm} / \mathrm{hr})$} \\
\hline & & Vertical & Horizontal \\
\hline \multirow{3}{*}{35} & 3 & - & - \\
\hline & 4 & - & - \\
\hline & 5 & - & - \\
\hline \multirow{3}{*}{40} & 3 & - & - \\
\hline & 4 & - & - \\
\hline & 5 & - & - \\
\hline \multirow{3}{*}{45} & 3 & - & - \\
\hline & 4 & - & - \\
\hline & 5 & - & - \\
\hline \multirow{3}{*}{115} & 3 & 116,4 & 971 \\
\hline & 4 & 300,8 & 1195,4 \\
\hline & 5 & 785 & 1366 \\
\hline
\end{tabular}

Table 6: Data Samples Recapitulation

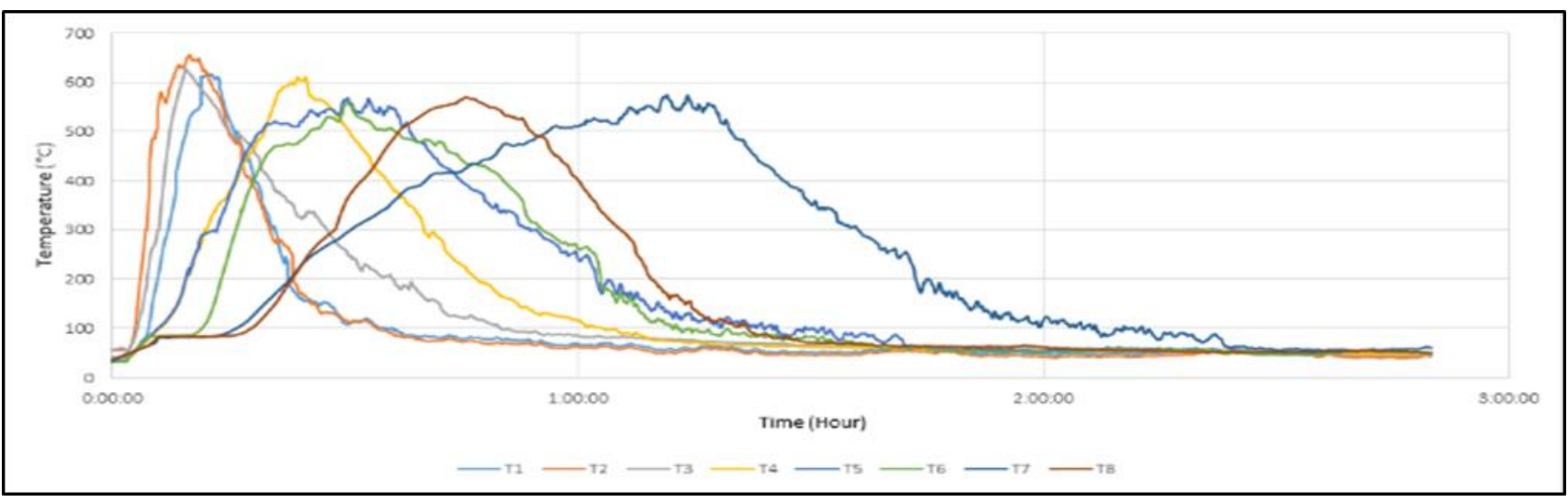

Figure 5: Smoldering Combustion at Speed of Airflow $3 \mathrm{~m} / \mathrm{s}$.

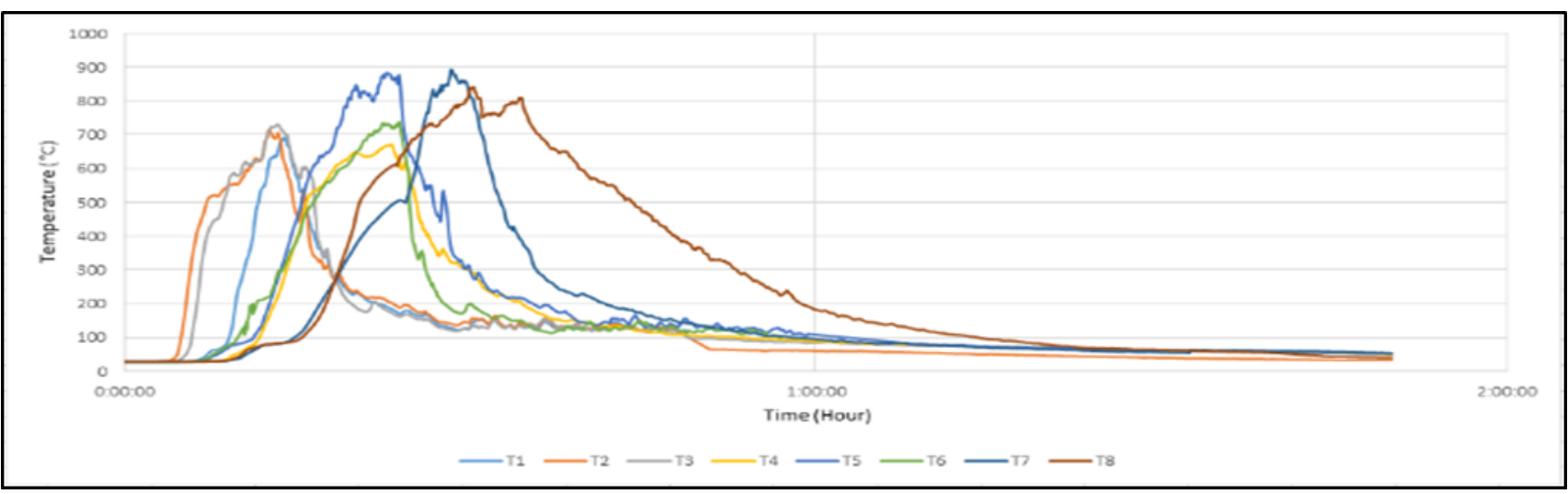

Figure 6: Smoldering Combustion at Speed of Airflow of $4 \mathrm{~m} / \mathrm{s}$. 


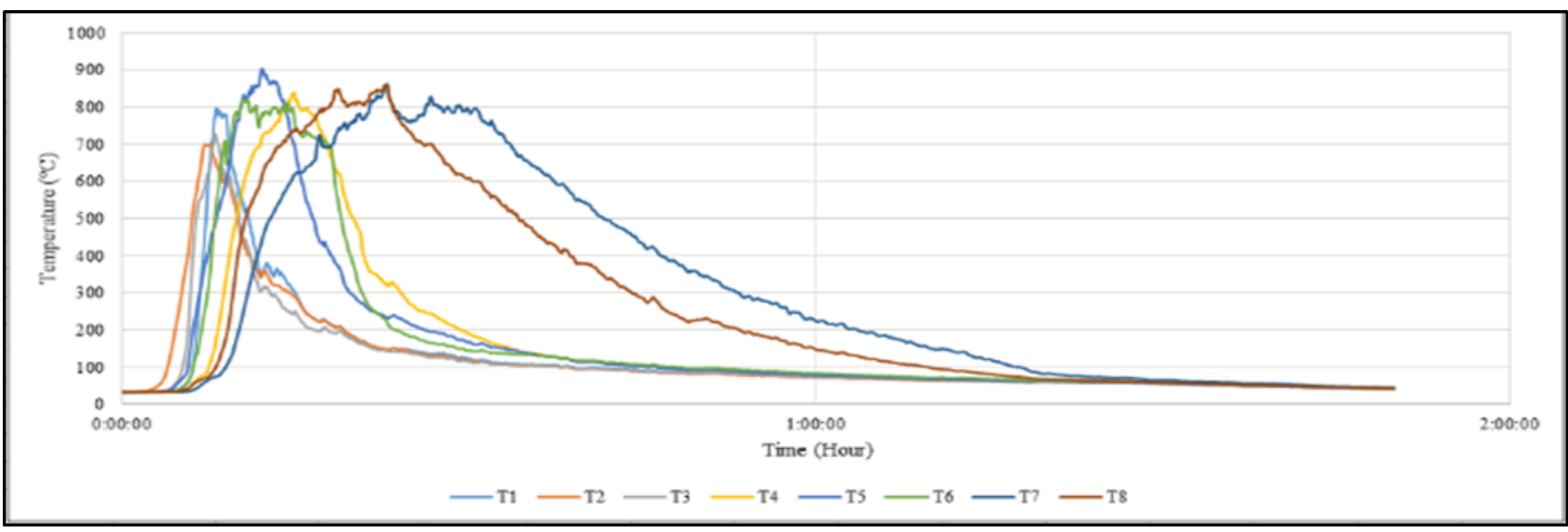

Figure 7: Smoldering Combustion at Speed of Airflow $5 \mathrm{~m} / \mathrm{s}$

In Figure 6, it can be seen the time needed to burn and propagate is faster than at an air flow velocity of $3 \mathrm{~m} / \mathrm{s}$. This can be seen on the faster temperature rising points of 1-3 and temperature rising points of 4-6, which is also faster, likewise at points of 7 and 8. It can show in Figure 7 that a similar event occurs in combustion with an air flow of $4 \mathrm{~m} / \mathrm{s}$ that the rate of combustion and propagation also occurs. In Figure 7 , it is presented that the combustion and propagation processes at an air flow rate of $5 \mathrm{~m} / \mathrm{s}$ occur faster than at air flow rates of $3 \mathrm{~m} / \mathrm{s}$ and $4 \mathrm{~m} / \mathrm{s}$, so it can be concluded that the given air flow velocity will affect to the rate of combustion and propagation. In figure 5,6 and 7 it is show that when all the temperatures decrease to the ambient temperature, that mean all samples have been burned out.

\subsection{CONCLUSION}

Cigarette butts are lit and placed on peat that have been dried at temperature of $35-45^{\circ} \mathrm{C}$, it is not cause the peat combustion. Cigarette butts are lit and placed on the peat sample that dry at $115^{\circ} \mathrm{C}$ with the addition of an airflow of $3 \mathrm{~m} / \mathrm{s}, 4 \mathrm{~m} / \mathrm{s}$ and $5 \mathrm{~m} / \mathrm{s}$ causing the peat combustion.

The fastest of smoldering combustion propagation velocity was obtained $785 \mathrm{~mm} /$ hour for vertical direction and $1336 \mathrm{~mm} /$ hour for horizontal direction with speed of airflow of $5 \mathrm{~m} / \mathrm{s}$. The highest temperature was obtained in the experiment of $902^{\circ} \mathrm{C}$ with the speed of airflow of $5 \mathrm{~m} / \mathrm{s}$.

\section{REFERENCES}

[1] Clara, L., Fatma, R., Viridiana, A \& Lies, W. (2017). Soil Organic Carbon the Hidden Potential, Food and Agriculture Organization of United Nation, Rome, Italy.
[2] Palamba, P, Ramadhan, M.L., Pamitran, A.S., Prayogo, G., Kosasih, E.A. \& Nugroho, Y.S. (2018). Drying Kinetics of Indonesian Peat, International Journal of Technology, 9 (5), 1006-1014.

[3] Saputra, E. (2019) Beyond Fires and Deforestation: Tackling Lang Subsidence in Peatland Areas, a Case Study from Riau, Indonesia, Land Journal, 8 (76), 1-24.

[4] Dohong, A. (2016). An Assessment of the Restoration Efforts of Degraded Peatland in Central Kalimantan Indonesia, PhD Thesis, School of Geography, Planning and Environmental Management, The University of Queensland.

[5] Matt, D.G., Kettridge, N., Stoof, C.R., Gray, A., Ascoli, D., Fernandes, P.M., Marrs, R., Allen, K.A., Doerr, S.H., Clay, G.D., McMorrow, J. \& Vandvik, V. (2016) the Role of Fire in UK Peatland and Moorland Management: The Need for Informed, Unbiased Debate, Philosophical Transactions of the Royal Society B Biological Sciences, 371 (1696), 20150342.

[6] FAO Forestry Paper (2016) Forestry for a Low-Carbon Future: Integrating Forest and Wood Products in Climate Change Strategies, Food and Agriculture Organization of United Nation, Rome, Italy

[7] Martin, A., Orion, H, Sandhyavitri, A., Palamba, P. \& Nugroho, Y.S. (2019). Smoldering Combustion Propagation of Subtropics Peat; Case Study on Pelalawan Peat, IOP Conf. Series, Materials Science and Engineering 539 (2019) 012029.

[8] Rogers, G. \& Simeoni, A. (2013) Proceedings of fourth Fire Behavior and Fuels Conference, Missoula, Montana, International Association of Wildland Fire.

[9] Setiawan, A. (2018). Kebijakan Penanganan Kebakaran Hutan dan Lahan di Indonesia, Journal of Political Ecology.

[10] Rein, G., Cleaver, N., Ashton, C., Pironi, P. \& Torero, J.L. (2008). The Severity of Smoldering Peat Fires and Damage to the Forest Soil, Catena, 74(3),304-309. 